\title{
Difficulties Encountered by EFL Students in Learning Pronunciation: A Case Study of Sudanese Higher Secondary Schools
}

\author{
Zahir Adam Daff-Alla Ahmed ${ }^{1}$ \\ ${ }^{1}$ Faculty of Education, Blue Nile University, Sudan \& Department of English Language, College of Science \& \\ Arts-Qilwah, Al-Baha University, Al-Baha, Kingdom of Saudi Arabia \\ Correspondence: Zahir Adam Daff-Alla Ahmed, Department of English Language, College of Science \& \\ Arts-Qilwah, Al-Baha University, Al-Baha, Kingdom of Saudi Arabia. Tel: 966-535-434-971. E-mail: \\ zahiradam20@gmail.com
}

Received: February 2, 2017 Accepted: March 8, 2017 Online Published: July 15, 2017

doi:10.5539/ijel.v7n4p75 URL: http://doi.org/10.5539/ijel.v7n4p75

\begin{abstract}
This study aims at investigating the problems which have been encountered by higher secondary schools students when they try to learn English pronunciation. The problem of this study is that most of the higher secondary school students in Sudan produced incorrect pronunciation for many of English words. So this study is attempted to deal with problem to find the most suitable solutions for it. The participants are Sudanese students of higher secondary schools especially at Shikan locality in Northern Kordofan State. The researcher uses the descriptive analytical approach because it is suitable for such studies. The data of this study is collected by means of recording test and questionnaire. The findings showed that the problems of pronunciation are the result of many teaching difficulties, and the strategies of teaching pronunciation are helpful in producing correct speech pronunciation. Finally the researcher recommends that: Sudanese EFL learners, who are specialized in ELT, should obtain a high level of intelligibility, and the language laboratory should exist in all the higher secondary schools to practice phonetic exercises.
\end{abstract}

Keywords: EFL learners, English pronunciation, language laboratory, learning process

\section{Introduction}

Nowadays, the development of science and technology has generated a great demand of intercommunicating. In order to meet this demand, English has become an international language and very important and compulsory subjects at schools. As a result, teaching English has become a compulsory subject at schools for many years.

Moosa (1972) and Homidan (1984) stated that Arab students encounter problems in the pronunciation of sounds which the students are not familiar with e.g., /v/, /p/, /y/. Nation (2009) stated, "When some teachers and students complain about difficulties in speaking, they are often talking about pronunciation" (p. 75). Pronunciation also plays a very important role in learning a language, as Derwing \& Munro (2005) claimed that, "having good pronunciation of the language can help in normal communication, particularly intelligibility."

In the light of Communicative Language Teaching (CLT), students are required not only to have good knowledge of vocabulary and eligible grammar, the four language skills, but also correct pronunciation. Accurate pronunciation is must be achieved in learning English process. Therefore, learning English pronunciation is of great importance to students, even for their exams or in general language communication. In addition, this will help them to have a good job in their future and enable them to communicate with foreigners successfully if they have a chance and the need.

Despite realizing this importance, Sudanese students still cannot acquire correct English pronunciation. The main reason is that the traditional teaching laid the emphasis on grammar, which led to this problem and the teachers themselves participate in this problem. Many students cannot pronounce English words and sentences correctly. They often pronounce them with equal stress, flat intonation and no rhythm at all. English pronunciation seems has become the most serious problem that students meet when they learn English. This is happening at the most of Sudanese higher secondary school.

This study tried to answer the following research questions:

1) What are the problems face EFL learners in learning English pronunciation? 
2) What are the causes of the pronunciation problems?

Thus, the importance of this study is to discover the problematic area of pronunciation and identifies the exact sounds that Sudanese EFL learners mispronounce and find the most useful solutions for it.

\section{Literature Review}

\subsection{Introduction}

A language is considered as a system of communicating with other people, using sounds symbols to express a meaning, idea or thought. Using language to communicate should be central in classroom of English language learning. Many researchers on second language acquisition found that the English pronunciation problems among speakers of other languages are the same but it is according to each language background. English language plays a significant role in our everyday life. Therefore, learning English is needed. The aim of this study is to investigate the difficulties encountered by EFL students in learning pronunciation. The researcher belief that learning pronunciation be a part of the material of English course, because good pronunciation can give learners self-confidence when they speak in front of many people. EFL learners should practice pronunciation and train themselves.

\subsection{Teaching English Pronunciation}

Many learners of English language often don't pay attention to their pronunciation, they belief that pronunciation is less important than another areas of English language. Many mistakes of misunderstanding in communication were caused by the mispronouncing of words. When we teach English pronunciation as a foreign language, the main goal is to make our students communicate easily with other people. Pronunciation is the area of teaching which neglected. Teach good pronunciation to students will make the better English listeners and learners. The field of modern language learning has developed the general approaches for teaching pronunciation. The communicative approach originated in 1980s, suggested that using language to communicate should be central in all classrooms language instructions. Intelligible pronunciation is necessary for communication to take place. Teachers of English language found that emphasis on rhythm, word stress, sentence stress and intonation is the best way to teach pronunciation to nonnative students. Teachers of English as a foreign language who are not native speakers of English and the learners in nonnative speaking countries require special care and assistance with pronunciation.

\subsection{Factors Affecting the Students of Pronunciation}

\subsubsection{Accent, Stress, Rhythm, Intonation}

Accent is a distinctive mode of pronunciation of a language, one associated with a particular nation, locality or social class. Schaetzel (2009) stated that there is important factors that one person must notice in the way of learning pronunciation which are accent, stress, intonation, and rhythm. Accent is defined by Schaetzel "as the cumulative auditory effect of those features of pronunciation that identify where a person is from regionally or socially". The goals of a learner is to sound as native. Stress syllables are often defined as those syllables with an utterance that are longer, louder and higher in pitch, it is the degree of force with a syllable or a word is uttered. When a word has more than one syllable, there is always one syllable that has greater stress than the others. Stress is an important feature of English pronunciation. A part of the meaning of a word depends on stress, it service to mark the function of words in spoken English. English pronunciation depends on stress to a great deal in order to become a powerful communicator of English language. Intonation is the forms or waves of language acquires while the speaking is produced, that means the melody or music of language, the voices rises and falls as we speak. The rhythm is usually produced by making certain notes in a sequence stand out of the form, others by being louder or longer or higher. Crystal (2003), stated that rhythm is organized according to regulating in timing of the stressed syllables. Rhythm is useful in communicating and enables the learners to divide speech into words or other units.

\subsubsection{The Age}

Selinker (1972) stated that "most adult second language learners never achieve native-live proficiency in TL". Their pronunciation continues to interfere with their ability to communicate effectively. According to the "Critical Period Hypothesis there is a biological timetable and beyond the age of puberty is more difficult to acquire a foreign like accent. Children under this age are likely to acquire a foreign like accent if they are exposing to the language in authentic contexts. Depending on the age of people, they have accurate perception of the sounds of the new language. Lenneberg (1967) hypothesized that language could be acquired only by a critical period, extending from early infancy until puberty. People who learned English when they were children, they think in English and use it naturally. 


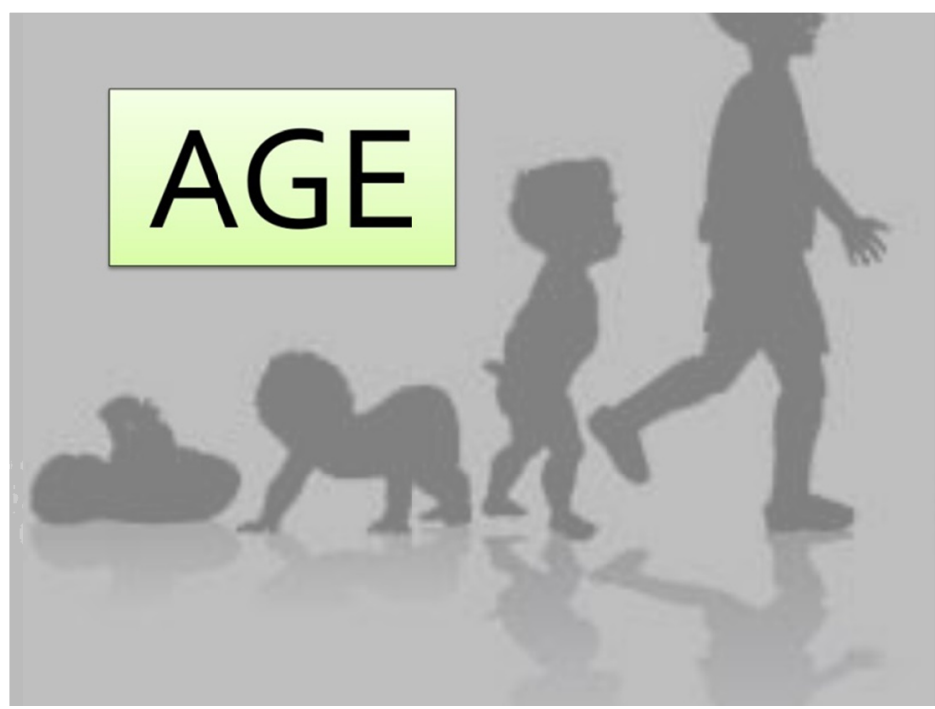

Figure 1. Age effects on learning pronunciation

\subsubsection{Motivation and Exposure}

Brophy (2010) describes students' motivation as the extent to which students will invest time, energy, and attention towards various tasks, goals or activities. Student motivation can affect current learning as well as the skills and strategies learnt previously Schunk et al. (2008). Motivation is the strength that pushes the person to achieve a goal; if the learners don't have motivation the learning process is harder. Motivation is the values, beliefs, and behaviors surrounding learning process. Some productive values and beliefs may lead to excitement, yet other values may lead to determined hard work. When we motivate our students we make them learn better than those who show no interest.

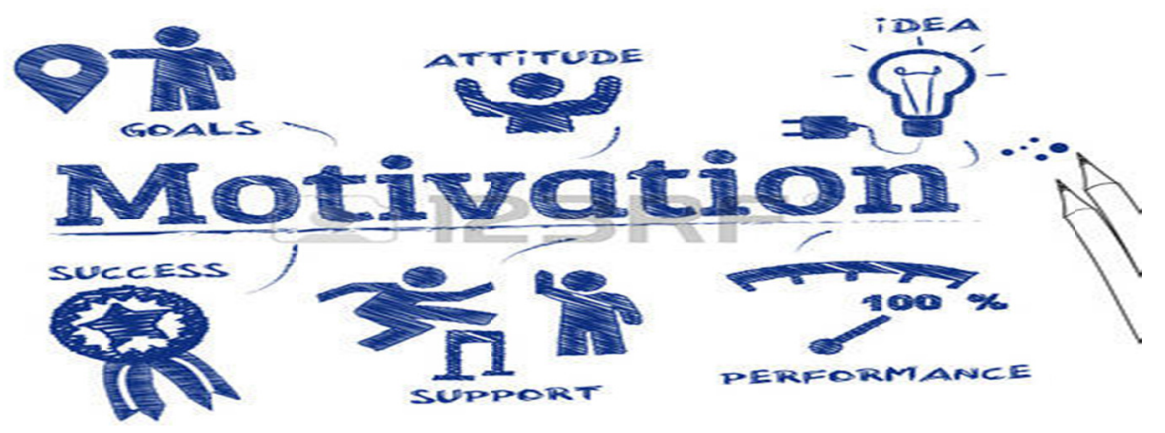

Figure 2. Motivation concept. Chart with keywords and icons (motivation, coaching, and training)

Roger Brown (1973) said that "the despite individual differences in rate of language learning, all first language learners seem to progress through different stages of acquisition." Human beings have the same ability to acquire the language, but the social environment has a great effect, because the students are going to learn the language which is exposed to, not the language that his or her parents speak. Exposure is important, because it is going to help the students to have models to be followed and to make comparisons between different English varieties. 


\section{AMOUNT OF EXPOSURE}

- Living in the right enviroment can help to improve our pronunciation.

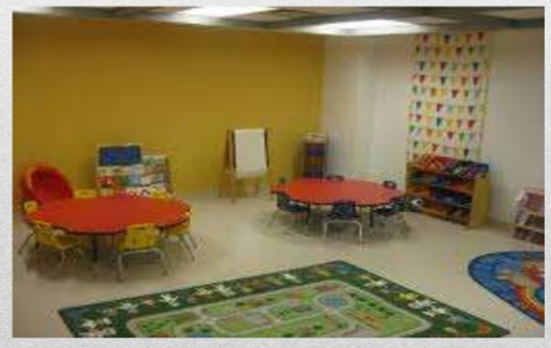

Figure 3. Amount of exposure

\subsubsection{Phonetic Ability}

The learners who live in English speaking environment acquire better pronunciation because they are impressed in the language. But not all the students are impressed in English speaking environment. Students have different phonetics abilities due to biological and physiological differences. Some are better at imitating sounds than others. The degree to which they are exposed to English on a daily basis will determine how fast they will be improving their pronunciation. Children were born with the ability to acquire any language, and possibly, the actual knowledge of linguistics universals.

\subsubsection{Attitude}

Researchers and studies indicate that the students with positive attitudes towards learning English learn faster, and students who are genuinely open minded and interested in improving their pronunciation often improve it. Dornyei as cited in Despagne (2003) stated that attitudes are created, and can be changed, through family, teachers, peers and school. The attitude of the students is strongest barrier found by them, because they don't feel that learn English is important and most of them don't have perspectives to future, they are living day by day.

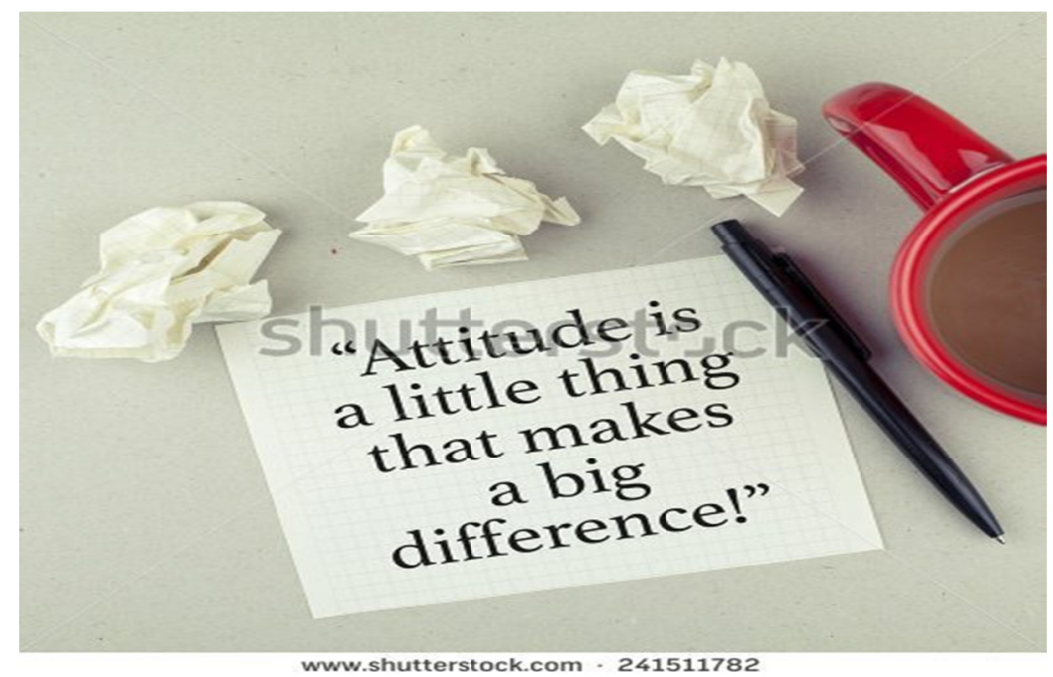

Figure 4. Attitude plays a big role in defining life as a whole 


\section{Method}

The aim of this study is to investigate the difficulties that face EFL learners in learning pronunciation. The researcher followed the descriptive and analytic statistic method in this study. This study is conducted in Sudan, Sudanese students of higher secondary schools especially at Shikan locality in Northern Kordofan State Academic year 2014/2015. Recording test for the students and a questionnaire is distributed to be answered by the higher secondary schools teachers to write their opinions and ideas about the exact reasons that make difficulties in learning pronunciation, and suitable ways that help them improve their pronunciation. All the data were analyzed later on statistical and descriptive basis.

\subsection{Sample of the Study}

The sample of study contains the English language teachers and students at secondary schools in Northern Kordofan State. The purposive sample consists of (35) students selected randomly and (50) teachers randomly selected from different schools to answer the questionnaire.

\subsection{Data Collection}

The researcher used two tools to collect data. These tools were a questionnaire and a recording test; they were designed to give accurate evaluation of the problems that face EFL students in learning pronunciation.

\subsubsection{Questionnaire}

50 copies of English language questionnaires were distributed to teachers from different universities, which served to verify the hypotheses and achieve the objective of the study. The questionnaire was handed out by the researcher to the participants. Then gathered and analyzed.

\subsubsection{Recording Test}

In testing the pronunciation errors, the researcher prepared (7) sentences written on a paper in each sentence there was a target sound, each of the students read the whole sentences a loud and the researcher was recording the pronunciation.

\subsection{Data Analysis}

To analyze the data, the researcher used two methods: first a descriptive analytical method was used to show the directions of the sample size of analytical study to show the difficulties that face EFL learners in learning pronunciation. Second factor analysis was used to discuss the hypotheses and support the research questions.

\section{Results and Discussion}

The researcher analyzed the data and discussed the results to answer the research questions. (1) what are the problems face EFL learners in learning English pronunciation? (2) What are the causes of the pronunciation problems?

\subsection{Results of Questionnaire}

The questionnaire was analyzed and displayed by means of tabulation and part chart. The chart was chosen because a quick look at it gives the reader full information about the items analysis.

Table 1. Problems affected on learning pronunciation

\begin{tabular}{llll}
\hline Questionnaire item & disagree & to some extent & agree \\
\hline Stress intonation considered as main problem of Learning pronunciation. & $7 \%$ & $33 \%$ & $60 \%$ \\
Mother tongue affect negatively on EFL learning pronunciation. & $8 \%$ & $12 \%$ & $80 \%$ \\
The syllabus requires many changes to suit learning pronunciation. & $0 \%$ & $25 \%$ & $75 \%$ \\
\hline
\end{tabular}

The table above confirms that $60 \%$ of the sample agreed that the stress and intonation considered as main problem of learning pronunciation. Also the $80 \%$ indicated that the mother tongue influence negatively on pronunciation process, and $75 \%$ of the respondents agreed that the syllabus may requires many changes to suit learning pronunciation. 
Table 2. Causes of pronunciation problems

\begin{tabular}{llll}
\hline Questionnaire item & disagree & to some extent & agree \\
\hline The lack of trained teachers affect negatively on teaching pronunciation & $0 \%$ & $10 \%$ & $90 \%$ \\
Non-qualified teachers are not able to teach the pronunciation effectively. & $10 \%$ & $30 \%$ & $60 \%$ \\
\hline
\end{tabular}

Table 2 shows that the majority of the respondents agreed with, the lack of the trained teachers affect negatively on teaching pronunciation, and $60 \%$ agreed that the non-qualified teachers are not able to teach pronunciation effectively.

Table 3. Effective strategies for teaching pronunciation

\begin{tabular}{llll}
\hline Questionnaire item & disagree & to some extent & agree \\
\hline Using of an attractive strategies of teaching enhance learning pronunciation. & $8 \%$ & $16 \%$ & $76 \%$ \\
$\begin{array}{l}\text { Foreign teachers for teaching pronunciation are one of the useful methods for } \\
\text { producing accurate sounds. }\end{array}$ & $5 \%$ & $10 \%$ & $85 \%$ \\
\hline
\end{tabular}

According to the table above, $76 \%$ of the sample agreed that the attractive strategies enhance learning pronunciation, and $85 \%$ confirmed that the foreign teachers are useful in teaching English pronunciation.

\subsection{Results of Recording Test}

Recording test is very important tool and the aim of this test is to investigate the problems of the students in learning pronunciation among the Sudanese secondary schools. This recording test was discussed and analyzed. In testing the errors of pronunciation of the Northern Kordofan State, (7) sentences written on a paper in each sentence there was a target sound for instance / $/ 2$ in the word "about". The sample of this study were 35 students from various secondary schools at Elobied town, all of them were Sudanese. The test is for second class. Each of the students read the sentences a loud and the researcher was recording their pronunciations.

After the 35 students recorded their pronunciation, the researcher later listened to the samples' recorded pronunciations for many times and then wrote down the number of students with correct pronunciations and the students with incorrect pronunciations. The figures were analyzed descriptively, percentages were computed. The statistics used in this study for recorded test and percentages from the data collected were computed.

The recorded sounds were counted to see the total number of the correct and incorrect answers. For e.g. in the test of $/ \mathrm{s} /$ sound in word 'pronounce' the whole number of students who pronounced the sound were (35), the number of students with correct pronunciation was (11). To calculate the percentage the following process was followed:

No. of students with correct pronunciation $=\frac{11}{35} \times 100=31.4 \%$

The above indicates that the only 31.4 of the students with correct pronunciation and the majority of the sample with incorrect pronunciation.

No. of students with incorrect pronunciation $=\frac{24}{35} \times 100=68.6 \%$

The above process shows that 68.6 of the whole students were not able to pronounce /a / sound correctly.

The recording test support that there are many difficulties face students in learning pronunciation. The whole data of this study were analyzed descriptively and statistically.

Table 4. The pronunciation of some English vowels by secondary schools students in Sudan, Northern Kordofan, Elobied town

\begin{tabular}{lllllll}
\hline Word & $* \mathrm{TS}$ & $* * \mathrm{NS}$ & $* * * \mathrm{NSC}$ & $\%$ & $* * * *$ NSI & $\%$ \\
\hline go & / əひ / & 35 & 13 & 37.1 & 22 & 62.9 \\
sheep & / i: $/$ & 35 & 10 & 28.6 & 25 & 71.4 \\
pronounce & / ə/ & 35 & 11 & 31.4 & 24 & 68.6 \\
important & / o: / & 35 & 28 & 80 & 7 & 20 \\
\hline
\end{tabular}

Note. $* \mathrm{TS}=$ Target sound, $* * \mathrm{NS}=$ number of students, $* * * \mathrm{NSC}=$ number of students with correct pronunciation, $* * * * \mathrm{NSI}=$ number of students with incorrect pronunciation. 
The above table shows that $37.1 \%$ of the participants are able to give correct pronunciation of the target sound in the word "go" and $62.9 \%$ with incorrect pronunciation of the target sound. In the word "sheep" only $28.6 \%$ were able to pronounce the target sound correctly, and the majority of sample with incorrect pronunciation. In the word "pronounce" the target sound was /a/ only $31.4 \%$ pronounce correctly and the rest $68.6 \%$ pronounce incorrectly. For the word (important) the target sound was $/ \mathrm{s}$ / / the majority of respondents $(80 \%)$ and only $20 \%$ were incorrectly. According to the result most of the participants were not able to pronounce vowels correctly.

Table 5. The pronunciation of some English consonants by secondary schools students in Sudan, Northern Kordofan, Elobied town

\begin{tabular}{lllllll}
\hline Word & TS & NS & NSC & $\%$ & NSI & $\%$ \\
\hline expensive & $/ \mathrm{p} /$ & 35 & 10 & 28.5 & 25 & 71.5 \\
such & $/ \mathfrak{t} /$ & 35 & 15 & 42.8 & 20 & 57.2 \\
then & $/ \delta /$ & 35 & 4 & 11.4 & 31 & 88.6 \\
thief & $/ \theta /$ & 35 & 6 & 17.1 & 29 & 82.9 \\
\hline
\end{tabular}

From the above table, only $28.5 \%$ of the sample was able to pronounce the sound $/ \mathrm{p} /$ correctly and $71.5 \%$ were pronounced incorrectly. In the second word 'such' $42.8 \%$ were correctly pronounced the target sound and the $57.2 \%$ with incorrect pronunciation of the target sound. In the word 'then' only $11.4 \%$ pronounced the target sound correctly and $88.6 \%$ incorrectly pronounced. Also the in the word 'thief' $17.1 \%$ of the students were able to pronounce the sound correctly, and $82.9 \%$ pronounced it incorrectly. According to the result the majority of the participants were unable to pronounce the English consonants that don't exist in Arabic and other consonants.

\section{Conclusion and Recommendations}

The study investigated the area of difficulties that face students in learning pronunciation in Northern Kordofan state, in Elobeid higher secondary school. The purpose of the study is to identify the problems that face students when learning pronunciation and attempted to find suitable solutions to the problems. The questionnaire and the test are used to measure the factors that influence reading comprehension abilities. The questionnaire was given to teachers of English language and the recording test was given to students. The researcher hopes that this study will offer suitable solutions of the difficulties in learning pronunciation.

The findings showed that there many problems face students in learning pronunciation such as: the stress and intonation considered as main problem of learning pronunciation, the mother tongue influence negatively on pronunciation process and the syllabus may require many changes to suit learning pronunciation.

\subsection{Recommendations}

A number of recommendations can be suggested according to the results and findings of the study: A need of qualified teachers to teach English pronunciation, using of an attractive and a suitable strategy to teach learning pronunciation (language Labs), foreign teachers are needed for teaching pronunciation, and learners need to be taught pronunciation as all other aspects of language.

\section{Acknowledgements}

I would like to send my thanks and gratitude to all my colleagues for their helpful and support. Particularly, I wish to express my thanks to Dr. Abdelaziz Mohammed and Dr. Hussein Assaggaf for their guidance throughout this study.

\section{References}

Brophy, J. (2010). Motivating students to learn (3rd ed.). Madison Avenue, Ny: Routledge.

Brown, R. (1973). A first language: The early stages. Cambridge, MA: Harvard University Press. https://doi.org/10.4159/harvard.9780674732469

Crystal, D. (2003). A dictionary of linguistics and phonetics. Oxford: Blackwell.

Davis, C. (1999). Will the use of videos designed for the purpose of teaching English pronunciation improve the learners' production of discrete sounds by at least $80 \%$ over a 12 -week period? In Action Research Monographs. Pennsylvania Action Research Network. A Section 353 Project of the Pennsylvania Department of Education, Bureau of Adult Basic and Literacy Education. ERIC Document [ED440 219].

Derwing, T. M., \& Munru, M. J. (2005). Second language accent and pronunciation teaching: A researcher—based approach. TESOL Quarterly, 39(3), 379-397. http://dx.doi.org/doi:10.2307/3588486 
Dornyei, Z. (2003) Attitudes, and Motivations in Language Learning: advance in theory, research, and applications. In Attitudes, Orientation, and Motivations in Language Learning. In Despagne (2010) the difficlties of learning English. Perceptions and attitudes in Mexico.

Homidan, A. H. (1984). Utilizing the Theory of Articulatory Settings in the Teaching of English Pronunciation to Saudi Students Learning English as a Second Language. Doctoral Dissertation, King Fahd Public Library.

Lenneberg, E. H. (1967). Biological foundations of language. New York: John Wiley \& Sons.

Moosa, M. H. (1972). Difficulties of Learning the Pronunciation and Structural Differences Between Arabic and English. MA Dissertation, Library of Saudi Arabia, Educational mission; Texas.

Nation, I. S. P., \& Newton, J. (2009). Teaching ESL/EFL listening and speaking. New York: Routledge, Taylor and Francis.

Schaetzel, K. (2009). Teaching Pronunciation to Adult English Language Learners. Washington, DC: CAELA Network Brief.

Schunk, D. H., Pintrich, P. R., \& Meece, J. L. (2008). Motivation in education theory, research, and application (3rd ed.). Upper Saddle River, N.J.: Person Prentice Hall.

Selinker. (1972). “Interlanguage” International Review of Applied Linguistics in Language Teaching.

\section{Copyrights}

Copyright for this article is retained by the author(s), with first publication rights granted to the journal.

This is an open-access article distributed under the terms and conditions of the Creative Commons Attribution license (http://creativecommons.org/licenses/by/4.0/). 